\title{
IMPLEMENTATION OF AUSM+'-UP SCHEME WITH IMPLICIT RESIDUAL SMOOTHING INTO OPENFOAM
}

\author{
Vojtěch Běták ${ }^{1}$; Jiř́i Fürst ${ }^{2}$ \\ Czech Technical University, Faculty of Mechanical Engineering, \\ Department of Technical Mathematics, Karlovo nám. 13, 12135 Praha 2, Czech Republic \\ e-mail: ${ }^{1}$ betakvojtech@gmail.com; ${ }^{2}$ jiri.furst@fs.cvut.cz
}

\begin{abstract}
The standard installation of open-source package OpenFOAM consists of segregated solvers based on pressure-correction schemes. These schemes specify type of jobs that can be solved, mainly incompressible and subsonic compressible flows. This paper deals with the implementation of coupled scheme with $\mathrm{AUSM}^{+}$-up flux that allows solving fluid problems in all speed regimes. This scheme is complemented by the Implicit Residual Smoothing (IRS), which extends the region of stability. Therefore an increase in the speed of convergence is observed. Acceleration by factor 6 was achieved.
\end{abstract}

\section{Introduction}

There are many codes that allow solving problems of fluid mechanics. Mostly commercial codes are popular in industry because they provide adequate accuracy and stability for most of cases and they are well documented and prepared for everyday use. In-house codes are mostly opposite because they are oriented mostly on certain case and use of this code requiring more knowledge in mathematics and computer skills. There is another variant that are based on public codes where basic schemes and user interfaces are implemented and they can be easily modified. OpenFOAM is one of these packages which are mostly based on pressurecorrection schemes such as SIMPLE or PISO algorithms [7]. These algorithms allow solving especially cases of incompressible or subsonic compressible flow. There is missing an algorithm that is suitable for flow from subsonic incompressible regime $(0.1 \mathrm{Ma})$ to supersonic regime (e.g. $3 \mathrm{Ma}$ ).

The AUSM ${ }^{+}$-up scheme presented by Liou [2] was chosen. This algorithm allows solving the flow in a wide range of Mach numbers. Implementation of implicit variant of $\mathrm{AUSM}^{+}$-up is difficult if we are using standard resources of OpenFOAM. Therefore explicit variant of AUSM $^{+}$-up was chosen that is only conditional stable. This limitation of time step should lead to inefficient method especially in the case of viscous flow. This is the reason why the implementation of AUSM+up scheme was complemented by method of Implicit Residual Smoothing (IRS) [3, 4] in combination with Runge-Kutta method (RK) [3, 4, 6]. The resulting scheme has improved stability and speed of convergence.

\section{$1 \quad$ Numerical schemes}

\section{1 $\quad$ AUSM $^{+}$-UP}

Let us consider a hyperbolic system of equations described in (1) where $W=(\rho, \rho u, \rho E)^{T}$ is a vector of conservative variables in 1D.

$$
W_{t}+\nabla \cdot F=0
$$


The vector of fluxes $\boldsymbol{F}$ consists of convective $\phi, \psi$ and pressure parts $P$ as is shown in (2).

$$
\begin{gathered}
F=\phi \psi+P \\
\phi=\rho u, \psi=(1, u, H)^{T} \text { a } P=(0, p, 0)^{T}
\end{gathered}
$$

The numerical flux through cell boundary is then

$$
f_{1 / 2}=\phi_{1 / 2} \psi_{L / R}+p_{1 / 2}
$$

where

$$
\psi_{L / R}=\left\{\begin{array}{l}
\psi_{L} \text { if } \phi_{1 / 2} \geq 0 \\
\psi_{R} \text { if } \phi_{1 / 2}<0
\end{array},\right.
$$

and

$$
\phi_{1 / 2}=u_{1 / 2} \rho_{L / R}=a_{1 / 2} M_{1 / 2} \rho_{L / R}, \phi_{L / R}=\left\{\begin{array}{l}
\phi_{L} \text { if } M_{1 / 2} \geq 0 \\
\phi_{R} \text { if } M_{1 / 2}<0
\end{array}\right.
$$

Functions $p_{1 / 2}$ and $M_{1 / 2}$ are defined as

$$
\begin{gathered}
M_{1 / 2}=M_{(4)}^{+}\left(M_{L}\right)+M_{(4)}^{-}\left(M_{R}\right)+2 \frac{K_{p}}{f_{a}} \max \left(1-\sigma \bar{M}^{2}, 0\right) \frac{p_{R}-p_{L}}{\left(\rho_{L}+\rho_{R}\right)+a_{1 / 2}^{2}}, \\
p_{1 / 2}=P_{(5)}^{+}\left(M_{L}\right) p_{L}+P_{(4)}^{-}\left(M_{R}\right) p_{R}-K_{u} P_{(5)}^{+} P_{(5)}^{-}\left(\rho_{L}+\rho_{R}\right) f_{a} a_{1 / 2}\left(u_{R}-u_{L}\right) .
\end{gathered}
$$

Definitions of the used functions, constants as well as the complete derivation is shown in [2].

\subsection{Runge-Kutta}

The integration in time is achieved with the Runge-Kutta $[3,4,6]$ method

$$
\begin{gathered}
W^{j}=W^{n}, j=0 \\
W^{j+1}=W^{n}-\alpha_{j} \Delta t R\left(W^{j}\right) \\
W^{n+1}=W^{j}, j=m
\end{gathered}
$$

Where residuum $R$ in cell $i$ with volume $\left|\Omega_{i}\right|$ is defined as

$$
R_{i}=\frac{1}{\left|\Omega_{i}\right|} \sum_{j \in \text { neighbour }} F_{i j}
$$

Where $F_{i}$ is a component of vector $\boldsymbol{F}$ defined by equation (2).

It is shown e. g. in [6] that this scheme has a wider stability region than the explicit Euler scheme, although the time step is still severely limited by the stability condition $\left(\Delta t_{R K}=\kappa\left(\alpha_{j}\right) \Delta t_{\text {Euler }}\right)$ as is shown in tables 1 and 2 .

\subsection{Implicit Residual Smoothing}

Next improvement can be achieved with the so called Implicit Residual Smoothing (IRS) [3, 4]. The IRS method introduces a smoothing operator for residual $R$, i.e. instead of by eq. (11) 
one solves a smoothed version by eq. (12). Stability analysis in [3] has shown that the system of equations (12) is unconditionally stable.

$$
\begin{aligned}
& W^{n+1}=W^{n}-\Delta t R, \\
& W^{n+1}=W^{n}-\Delta t \tilde{R},
\end{aligned}
$$

Smoothed residuum $\widetilde{R}$ is defined as

$$
(1-\epsilon \Delta) \tilde{R}=R
$$

where $\epsilon$ is a smoothing parameter. System of equations (13) is solved by Jacobi iteration solver as is shown in (14).

$$
\tilde{R}=\frac{R+\epsilon \sum_{k}^{m} R_{k}}{1+\epsilon m} .
$$

Sometimes it is suitable (e.g. in the case of computational grid with local refinement) to use residual smoothing in the following form

$$
\tilde{R}=\frac{R+\epsilon \sum_{k}^{m} R_{k} \frac{\Psi_{k}}{\sum \Psi_{k}}}{1+\epsilon m}
$$

$\Psi_{k}$ is the weight defined by distance of two neighbor cells and face magnitude between these cells

$$
\Psi_{k}=\frac{s_{i j}^{2}}{\left|x_{i}-x_{j}\right|} .
$$

\section{Results}

The AUSM scheme with Implicit Residual Smoothing (IRS) and Runge-Kutta time marching were tested on two cases. In both cases three approximations of time derivatives are compared. The first one is a forward Euler scheme, the second one is a four-step Runge-Kutta scheme with coefficients $0.11,0.2766,0.5$ and 1 . The third one is a four-step Runge-Kutta (RK4) scheme with Implicit Residual Smoothing. 


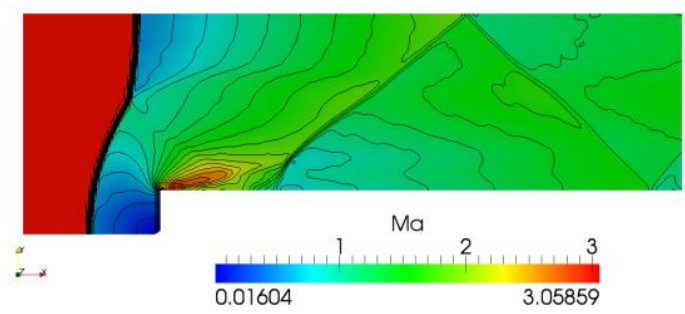

(a) rhoCentralFoam

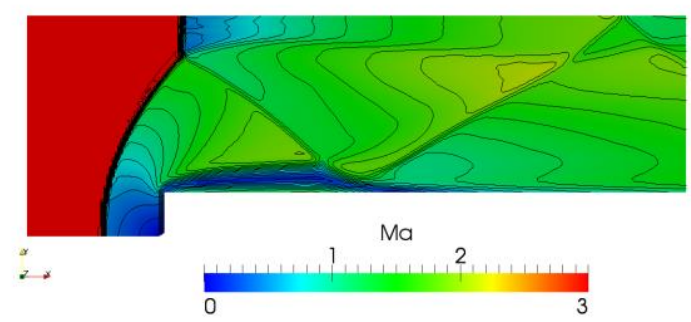

(c) $\mathrm{AUSM}^{+}$-up with RK-4

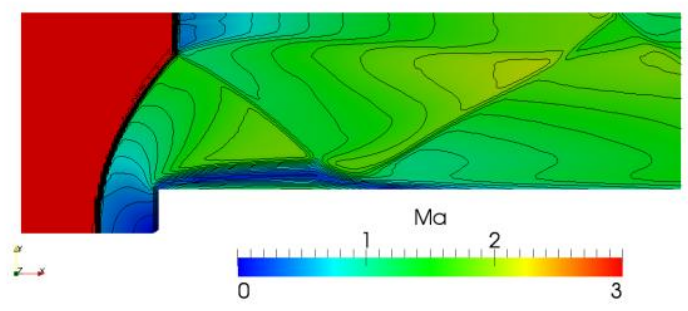

(b) $\mathrm{AUSM}^{+}$-up with Euler

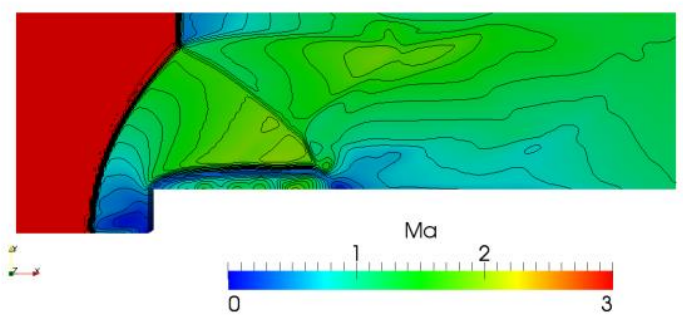

(d) $\mathrm{AUSM}^{+}$-up with RK-4 and IRS

Source: Own

Fig. 1: Forward facing step - Mach number

2D forward facing step is the first test case. The computational grid consists of $16 \mathrm{k}$ square cells. The flow is characterized by inlet Mach number $M=3$, the gas is assumed as an ideal gas with heat capacity ratio 1.4 . One can observe a difference between flow fields obtained by native OpenFOAM solver rhoCentralFoam based on Kruganov-Tadmor scheme and our implementation of $\mathrm{AUSM}^{+}$-up scheme as is shown in figures 1 (fields of Mach number) and 2 (pressure distribution on lower wall). All methods are consistent in the determination of front shock wave. The main difference is behind step where each algorithm predicts different structure of shock wave reflection and interaction. The change of time approximation between Euler and 4 stage Runge-Kutta scheme has no effect on flow field and pressure profile. These results are similar with results presented in [9]. If IRS is enabled the shock wave reflection from bottom wall is not captured and flow field is changed due residual averaging.

The stable time step and required time for solution of $10 \mathrm{~s}$ of physical time is shown in table 1. Application of Runge-Kutta method allowed increasing time step 5e-4 s ten times with reduction of computational time approximately to 1/3. If the IRS is enabled, the stable time step increases to $3 \mathrm{e}-2 \mathrm{~s}$ and reduces computational time approximately to $1 / 10$ of the original computational time.

Source: Own

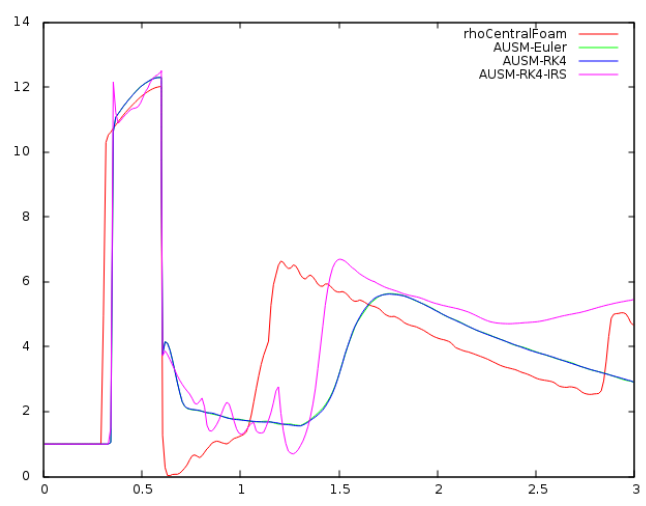

Fig. 2: Pressure on bottom wall of channel 
Tab. 1: Comparison of stable time step and solution time of 10 s physical time for different time integration settings

Source: Own

\begin{tabular}{|l|c|c|}
\hline & Stable time step [s] & Solution time [s] \\
\hline Euler & $5 \mathrm{e}-4$ & 568 \\
\hline RK4 & $5 \mathrm{e}-3$ & 220 \\
\hline RK4+IRS & $3 \mathrm{e}-2$ & 65 \\
\hline
\end{tabular}

In the second case the efficiency of various approximations were compared on 2D inviscid transonic flow around turbine blade SE-1050 (Fig. 2.) The computational domain consists of $6 \mathrm{k}$ triangular cells and it is constructed with periodic boundary conditions to simulate effect of infinite turbine cascade. This simulation was computed with following boundary conditions given in [8]

- total pressure $980717 \mathrm{~Pa}$ and temperature $298.65 \mathrm{~K}$ on inlet

- $\quad$ angle of attack $70,7^{\circ}$

- isoentropic outlet Mach number $\mathrm{M}_{2 \mathrm{i}}=1,19$

- thermo physical properties of the gas corresponds to air (neglecting the viscosity)

The $\mathrm{AUSM}^{+}$-up scheme captures two shock waves generated on trailing edge of blade and reflection of the inner branch from suction surface. It is possible to see a similarity between our and published results [8] in figure 3. AUSM ${ }^{+}$-up predicts the outlet Mach 1.15. This is slightly lower than assumed isoentropic Mach number 1.19 due to energy losses. Pressure distribution along blade is shown in figure 4 . There is an agreement between experimental and computed pressure distribution around blade.
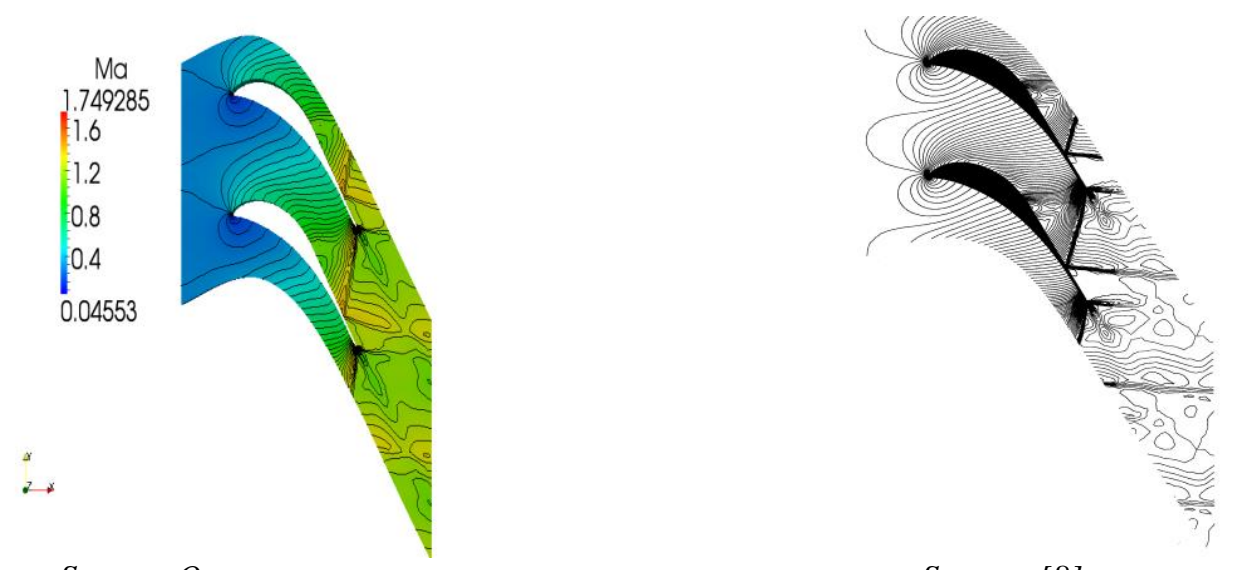

Source: Own

Source: [8]

Fig. 3: Comparison between computed and published Mach number fields 
Source: Own

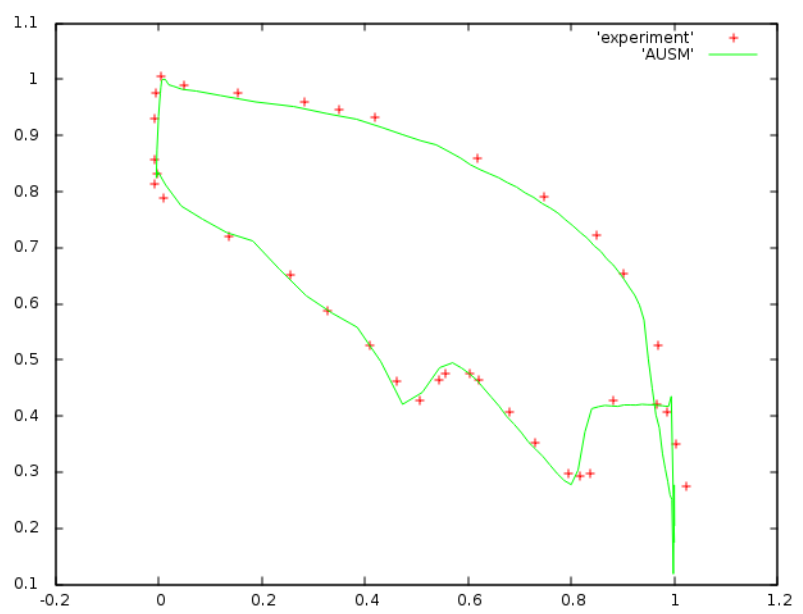

Fig. 4: Comparison of pressure distribution along blade

Four-step Runge-Kutta scheme with IRS allows to use 20 times higher time step and reduces the solution time approximately 6 times as is shown in table 2. Pure 4 step Runge-Kutta schemes allows to use 4 times higher time step but with similar computational cost.

Tab. 2: Comparison of stable time step and solution time of 0.0001 physical time

Source: Own

\begin{tabular}{|l|c|c|}
\hline & Stable time step [s] & Solution time [s] \\
\hline Euler & $5 \mathrm{e}-7$ & 210 \\
\hline RK4 & 2e-6 & 201 \\
\hline RK4+IRS & $1 \mathrm{e}-5$ & 36,6 \\
\hline
\end{tabular}

\section{Conclusion}

AUSM $^{+}$-up scheme which is possible to use in wide interval of velocities was implemented Into OpenFOAM. This scheme was supplemented by Runge-Kutta scheme and Implicit Residual Smoothing for improvement stability and convergence speed. The improvement was confirmed by simulation of two inviscid compressible cases. Implemented scheme is universal with wide range of applications. This scheme was used e. g. for simulation of 3D compressible flow in turbine cascade or test facilities for internal re-circulation surge suppression in latest time. There is a potential to apply this algorithm in the case of jet engine simulation especially for simulation of combustor - turbine interaction. Therefore it would be useful to extend computational algorithm for support of dynamic mesh, mesh refinement or combustion simulation.

The IRS is useful extension that is easy to implement by standard OpenFOAM operators. Future work will be oriented into coupling $\mathrm{AUSM}^{+}$-up and IRS with other OpenFOAM libraries for supporting combustion modeling, dynamic mesh refinement or motion.

\section{Literature}

[1] OpenCFD Ltd.: OpenFOAM - User Guide. [online]. 2014. [accessed 2015-04-01]. Available from WWW: www.openfoam.org/docs

[2] LIOU, M, S.: A sequel to AUSM, Part II: AUSM ${ }^{+}$-up for all speeds. Journal of Computational Physics, 2006, Vol. 16, Issue 4, pp. 4-13. ISSN 0021-9991. 
[3] TAI, C. H.; SHEU, J. H.; LEER, B.: Optimal Multistage Schemes for Euler Equations with Residual Smoothing. AIAA Journal, 1995, Vol. 33, No. 6, pp. 1008-1016. ISSN: 0001-1452.

[4] FOI - Swedish Defense Research Agency: EDGE: Theoretical Formulation. Stockholm, Sweden, 2007. ISSN-1650-1942. Available from WW: http://www.foi.se/Global/Customers\%20and\%20Partners/Projects/Edge/Documentation ledge-theory.pdf

[5] COQUEL, F.; NGUYEN, Q. L.; POSTEL, M.; TRAN, Q. H.: Local time stepping applied to implicit-explicit methods for hyperbolic systems. [online]. 2013. [accessed 2015-0401] Available from https://www.lj1l.math.upmc.fr/publications/2007/R07058.pdf

[6] MacDONALD, C. P.: Constructing High-Order Runge-Kutta Methods with Embedded Strong Stability Preserving Pairs. [online]. 2003. [accessed 2015-04-01]. Available from WWW: https://people.maths.ox.ac.uk/macdonald/mscthesis/cbm-mscthesis.pdf

[7] Velocity-pressure coupling. In: CFD-ONLINE-Wiki. [online]. [accessed 2015-04-01]. Available from WWW: http://www.cfd-online.com/Wiki/Velocity-pressure_coupling

[8] Silver: AC 6-12 CFD. In: ERCOFTAC QNET-CFD. [online]. [accessed 2015-04-01]. Available from WWW: http://uriah.dedi.melbourne.co.uk/w/index.php/AC_6-12

[9] WOODWARD, P.; COLELLA, P.: The Numerical Simulation of Two-Dimensional Fluid Flow with Strong Shock. Journal of Computational Physics, 1984, Vol. 54, Issue 1, pp. 115-173. ISSN 0021-9991.

Ing. Vojtěch Běták; doc. Ing. Jiří Fürst, Ph.D. 


\section{IMPLEMENTACE SCHÉMATU AUSM+-UP S IMPLICITNÍM VYHLAZOVÁNÍM RESIDUÍ DO SOFTWARU OPENFOAM}

Standardní instalace open-source balíku pro výpočetní mechaniku tekutin OpenFOAM je založena hlavně na schématech kombinujících tlak a rychlost. Tato schémata předurčují typy úloh, které je možné pomocí nich řešit (např. podzvukové nestlačitelné, stlačitelné nebo transsonické). Tento článek se zabývá implementací schématu $\mathrm{AUSM}^{+}$-up založeného na provázání hustoty a rychlosti, které umožňuje řešit problémy mechaniky tekutin v širším intervalu rychlostí. Toto schéma je doplněno o implicitní vyhlazování residuí, které rozšiřuje oblast stability použitého schématu. Proto je pozorován nárůst rychlosti konvergence použitého schématu, které bylo zrychleno šestkrát.

\section{IMPLEMENTATION DES AUSM+'-UP SCHEMAS MIT IMPLIZITER GLÄTTUNG VON RESIDUEN IN OPENFOAM SOFTWARE}

Die Standartinstallation eines Open-source-Pakets OpenFOAM für die Berechnung von Flüssigkeitsströmungen basiert hauptsächlich auf Lösungsschemen, die Druck und Geschwindigkeitsfelder verknüpfen. Diese Schemen geben auf diese Weise lösbare Aufgabentypen vor (z.B. Unterschallströmung, inkompressible/ kompressible oder transsonische Strömung). Dieser Artikel setzt sich mit der Implementierung des Schemas AUSM $^{+}$-up auseinander, das auf der Verknüpfung von Dichte und Geschwindigkeitsfeldern beruht. Die Lösung eines breiteren Aufgabenfeldes in der Flüssigkeitsberechnung wird dadurch ermöglicht. Mit Hilfe der Glättung von Residuen wird das Schema ergänzt, damit der Stabilitätsbereich erweitert wird. Auf Grund der berechneten Aufgabe wurde die Konvergenz stark beschleunigt und eine sechsfache Geschwindigkeitserhöhung beobachtet.

\section{WDRAŻANIE SCHEMATU AUSM+'-UP Z WYGŁADZANIEM REZYDUÓW W OPENFOAM SOFTWARE}

Standardowa instalacja pakietu open-source do obliczeniowej mechaniki płynów OpenFOAM oparta jest przede wszystkim na schematach łączących ciśnienie i prędkość. Schematy te określają rodzaje zadań, które można $\mathrm{z}$ ich pomocą rozwiązać (np. poddźwiękowe nieściśliwe, ściśliwe lub transsoniczne) Niniejszy artykuł poświęcony jest wdrażaniu schematu $\mathrm{AUSM}^{+}$-up opartego na powiązaniu gęstości i prędkości, które umożliwia rozwiązywanie problemów mechaniki płynów w szerszym przedziale prędkości. Schemat ten został uzupełniony wygładzaniem rezyduów, które rozszerza zakres stabilności zastosowanego schematu. Dlatego obserwowany jest wzrost prędkości konwergencji zastosowanego schematu, która została przyspieszona sześciokrotnie. 